\title{
Deciphering the molecular pathways disrupted in normal and neoplastic colonic tissue in inherited colorectal cancer syndromes
}

\author{
Deborah W Neklason ${ }^{1,4^{*}}$, Michelle W Done ${ }^{4}$, Brett Milash ${ }^{4}$, Lewis Frey ${ }^{2,4}$, Nykole Sargent ${ }^{1}$, Thérèse M Tuohy ${ }^{4}$, \\ Randall W Burt ${ }^{3,4}$ \\ From 14th Annual Meeting of the Collaborative Group of the Americas on Inherited Colorectal Cancer \\ Dallas, TX, USA. 12-13 October 2010
}

\section{Background}

Genetic profiling by RNA microarray of normal and neoplastic colonic tissue is used to identify biomarkers for development of a diagnostic tool for the inherited colon cancer syndromes. The utility of this method is to 1) properly classify patients where genetic diagnosis is incomplete 2) suggest molecular pathways that are shared between the syndromes and 3) identify molecular targets for prevention and treatment.

\section{Methods}

RNA was extracted from fresh colonic biopsies obtained during endoscopy. Agilent $44 \mathrm{~K}$ whole genome microarrays were run on 7-10 normal and neoplastic sample pairs from control, FAP, AFAP, Cowden syndrome, hyperplastic polyposis (HPP), and HNPCC (normal tissue only) patients. Microarray data were normalized, log-transformed, and analyzed for $>1.2$ fold differential expression using GeneSifter software with a t-test adjusted by the Benjamini and Hochberg method. The most significant 100 mRNA probes were selected for evaluation. Select genes were confirmed by real-time quantitative PCR. Pathway analysis was done using prior knowledge resources including Genespring, KEGG and Cytoscape with microarray derived models.

\section{Results}

The most significant 100 of 44,000 probes gave adjusted $\mathrm{p}$-values $<3 \times 10^{-4}$. Within this subset, the mRNAs from causative genes are decreased in normal colonic tissue

\footnotetext{
* Correspondence: deb.neklason@hci.utah.edu

'Department of Oncological Sciences, University of Utah, Salt Lake City, UT 84112-5550, USA

Full list of author information is available at the end of the article
}

from Cowden syndrome (PTEN), HNPCC (MLH1), and AFAP $(A P C)$ patients, but not from FAP $(A P C)$ patients, suggesting the presence of unstable mRNA and a molecular level of haploinsufficiency. The largest increased expression in HNPCC vs. controls included three genes with plekstrin homology domains (TRIOBP, PLEKHF1, FGD1), and two of these are also increased in Cowden syndrome (PLEKHF1, FGD1) along with SMAD5. There appear to be parallels between FAP and HPP. Normal HPP tissue has a decrease in NKD2 which is a negative regulator of the canonical WNT signaling pathway. Normal FAP (vs. control) and HPP polyp (vs. normal) demonstrate a disruption in MEKK4 (MAP3K4)-ANXA2PLG-MMP7 pathways. Additionally the proto-oncogene, $M E T$, is up-regulated in FAP and AFAP normal as well as HPP polyp tissues. MET is a tyrosine kinase HGF receptor; mutations are associated with hereditary papillary renal carcinoma and it resides in a genetic region associated with common familial colon cancer. This gene may have a central role in predisposing cells for a proliferative phenotype as it interacts with beta-catenin pathway.

\section{Conclusions}

Deciphering the molecular signatures of the inherited colon cancer syndromes has revealed, and will continue to reveal, interesting clues into pathways that are differentially regulated in normal colonic tissue, and those are altered during the neoplastic process.

\section{Disclosure and funding}

There are no financial interests to disclose. This research was funded by NIH grants RC1-CA146329 (RWB); R03-CA150067 (DWN); R01-CA040641 (RWB) and Huntsman Cancer Foundation. 


\section{Author details}

'Department of Oncological Sciences, University of Utah, Salt Lake City, UT 84112-5550, USA. ${ }^{2}$ Department of Biomedical Informatics, University of Utah, Salt Lake City, UT 84112-5550, USA. ${ }^{3}$ Department of Medicine, University of Utah, Salt Lake City, UT 84112-5550, USA. ${ }^{4}$ Huntsman Cancer Institute at University of Utah, Salt Lake City, UT 84112-5550, USA.

Published: 10 March 2011

doi:10.1186/1897-4287-9-S1-06

Cite this article as: Neklason et al: Deciphering the molecular pathways disrupted in normal and neoplastic colonic tissue in inherited colorectal cancer syndromes. Hereditary Cancer in Clinical Practice 2011 9(Suppl 1):O6.

Submit your next manuscript to BioMed Central and take full advantage of:

- Convenient online submission

- Thorough peer review

- No space constraints or color figure charges

- Immediate publication on acceptance

- Inclusion in PubMed, CAS, Scopus and Google Scholar

- Research which is freely available for redistribution

Submit your manuscript at www.biomedcentral.com/submit
C Biomed Central 